\title{
Paper Sector in Bangladesh: Challenges and Scope of Development
}

\author{
Dr. Engr. M M A Quader \\ Additional Chief Engineer, KPML, Chandraghona
}

\begin{abstract}
Pulp and paper sector in Bangladesh is used to get less importance in comparison with that of other sectors related to socioeconomic development of the country. KPML, the oldest integrated pulp and paper industry in Bangladesh built in the early fifties of last century is still in operation. Recently, almost hundred paper mills are erected and most of those are in operation and producing varieties of papers. This article deals with the problems in operating the mills and makes suggestions to improve its operation and productivity. The major challenges in paper sector and the scope of development is discussed.
\end{abstract}

\section{INTRODUCTION}

Paper provides the means of recording, storage and dissemination of information; virtually all writing and printing are done on paper. It is the most widely used wrapping and packaging material, and is important for structural applications (3). New specialty products are continually being developed. The Pulp \& Paper Industry provides employment for a vast number of people and plays a vital role in the overall economy of the world. The significance of paper and paper products in modern life is obvious to everyone.

Later part of the twentieth century has seen the rapid refinement and modification of the early and rather crude technology, along with the development of such techniques as drum-debarking, refiner/mechanical pulping, continuous cooking, $\mathrm{O}_{2}$-Delignification, continuous multistage bleaching, ECF/TCF bleaching concept, energy efficient Kraft Mill concept, minimum effluent pulp mill, effluent treatment system, closing the system, efficient recovery system, gasification concept, high speed paper machine, Fourdrinier to twin-wire former, gap-former, roll/roll-blade former, wide-nip press, soft calendaring, on-line super calendaring, online coating and advanced controls, diversity in packaging industries, etc.

BCIC - Bangladesh Chemical Industries Corporation had played an important role in the Pulp \& Paper sector in Bangladesh. BCIC now operates only the Karnaphuli Paper Mills (KPM) producing quality paper as well as packaging paper with yearly capacity of 30,000 MT and it was commissioned in 1953. Other mills under BCIC now closed include: KNM, SPPM and NBPM. The Khulna Newsprint Mill (KNM), only newsprint producing plant began production in 1959 with an annual capacity of 50,000 MT. The North Bengal Paper Mill (NBPM) was commissioned in 1973 with the capacity of 15,000 MT and it produced writing and printing paper using bagasse. The Sylhet Pulp \& Paper Mill (SPPM), the only pulp producing plant based on reeds began production in 1975 with an annual production capacity of 20,000 MT. The Magura Paper Mills producing packaging paper around $15000 \mathrm{MT}$ per year is a joint venture with BCIC. BCIC used to produce around $90 \%$ of the total paper used in Bangladesh 25 years ago. BCIC/KPM is today producing $<5 \%$ of the total paper used in Bangladesh. The private sector has taken over the paper sector in the country. The private sector paper mills includes: T.K. group (paper, board, tissue mill), Basundhar group (paper, tissue, newsprint), Creative paper mill, Capital paper mills, Hakkani paper mill, Hossain pulp \& paper mills, etc. Although, the private sector plays the major role in Paper \& Paper board production, KPML still is producing yearly 20,000-25,000 MT of different types of paper including specialty paper.

The per capita paper and board consumption in Bangladesh is about $3.5 \sim 4 \mathrm{~kg}$ and that in advanced countries is more the $300 \mathrm{~kg}$ and the world average is around $50 \mathrm{~kg}$ while the Asia average is around $30 \mathrm{~kg}$. If we grow up to Asia level, our consumption will increase to 10 times of current consumption. The per capita paper consumption as well as total paper consumption are increasing all over the developing countries and, also, in Bangladesh. It will increase further in future.

\section{PULP AND PAPER INDUSTRIES IN BANGLADESH}

The major pulp and paper industries in private sector in Bangladesh have grown in Dhaka and Chittagong regions. An overview of pulp and paper industries in Bangladesh is presented below: 
A. Dhaka region

\begin{tabular}{|c|c|c|c|}
\hline $\begin{array}{l}\text { S1. } \\
\text { No. }\end{array}$ & $\begin{array}{l}\text { Name of } \\
\text { the Paper } \\
\text { Mills }\end{array}$ & Paper grades & $\begin{array}{c}\text { Production, } \\
\text { TPD }\end{array}$ \\
\hline 1 & $\begin{array}{l}\text { Sonali Paper } \\
\text { Mills }\end{array}$ & Board & 25 \\
\hline 2 & $\begin{array}{l}\text { Sonali Paper } \\
\text { Mills }\end{array}$ & Writing & 30 \\
\hline 3 & $\begin{array}{l}\text { Islamia } \\
\text { Paper Mills }\end{array}$ & Media & 20 \\
\hline 4 & $\begin{array}{l}\text { Islamia } \\
\text { Paper Mills }\end{array}$ & Media & 20 \\
\hline 5 & $\begin{array}{ll}\text { Lina } & \text { Paper } \\
\text { Mills } & \\
\end{array}$ & Writing & 25 \\
\hline 6 & $\begin{array}{l}\text { Dhaka Paper } \\
\text { Mills }\end{array}$ & Media & 10 \\
\hline 7 & $\begin{array}{l}\text { Konik Paper } \\
\text { Mills }\end{array}$ & Writing & 30 \\
\hline 8 & $\begin{array}{l}\text { Konik Paper } \\
\text { Mills }\end{array}$ & Writing & 20 \\
\hline 9 & $\begin{array}{l}\text { Bengal } \\
\text { Packages } \\
\text { Ltd. }\end{array}$ & Media & 50 \\
\hline 10 & $\begin{array}{l}\text { Capital } \\
\text { Paper Mills }\end{array}$ & Media/Newsprint & 20 \\
\hline 11 & $\begin{array}{l}\text { Capital } \\
\text { Paper Mills }\end{array}$ & Media/Newsprint & 20 \\
\hline 12 & $\begin{array}{l}\text { Sadek Paper } \\
\text { Mills }\end{array}$ & Media & 20 \\
\hline 13 & BPN & Media & 35 \\
\hline 14 & $\begin{array}{ll}\text { Afil } & \text { Paper } \\
\text { Mills } & \\
\end{array}$ & Media & 20 \\
\hline 15 & $\begin{array}{ll}\text { Afil } & \text { Paper } \\
\text { Mills } & \\
\end{array}$ & Media & 15 \\
\hline 16 & $\begin{array}{ll}\text { R.S. } & \text { Paper } \\
\text { Mills } & \\
\end{array}$ & Media & 35 \\
\hline 17 & $\begin{array}{l}\text { Pioneer } \\
\text { Board Mills } \\
\end{array}$ & Media/Board & 22 \\
\hline 18 & $\begin{array}{l}\text { Magura } \\
\text { Paper Mills }\end{array}$ & Media & 45 \\
\hline 19 & $\begin{array}{l}\text { Magura } \\
\text { Paper Mills }\end{array}$ & Writing & 70 \\
\hline 20 & $\begin{array}{l}\text { Shahjalal } \\
\text { Newsprint } \\
\end{array}$ & Newsprint & 70 \\
\hline 21 & $\begin{array}{l}\text { Bashundhara } \\
\text { Tissue }\end{array}$ & Writing & 25 \\
\hline 22 & $\begin{array}{l}\text { Bashundhara } \\
\text { Tissue }\end{array}$ & Tissue & 20 \\
\hline 23 & $\begin{array}{l}\text { Bashundhara } \\
\text { Tissue }\end{array}$ & Media & 10 \\
\hline 24 & $\begin{array}{l}\text { Ananta } \\
\text { Paper Mill } \\
\end{array}$ & Media & 25 \\
\hline 25 & $\begin{array}{l}\text { Ananta } \\
\text { Paper Mill }\end{array}$ & Writing & 10 \\
\hline 26 & $\begin{array}{l}\text { Ananta } \\
\text { Board Mill }\end{array}$ & Board & 20 \\
\hline 27 & $\begin{array}{l}\text { Eastern } \\
\text { Paper Mill }\end{array}$ & Board & 20 \\
\hline
\end{tabular}

\begin{tabular}{|c|c|c|c|}
\hline 28 & $\begin{array}{l}\text { Eastern } \\
\text { Paper Mill }\end{array}$ & Newsprint & 10 \\
\hline 29 & $\begin{array}{ll}\text { Maq } & \text { Paper } \\
\text { Mill } & \end{array}$ & Media & 35 \\
\hline 30 & $\begin{array}{ll}\text { Maq } & \text { Paper } \\
\text { Mill } & \\
\end{array}$ & Writing & 20 \\
\hline 31 & $\begin{array}{ll}\text { Maq } & \text { Paper } \\
\text { Mill } & \\
\end{array}$ & Simplex & 10 \\
\hline 32 & $\begin{array}{l}\text { Azad Board } \\
\text { Mill }\end{array}$ & Media & 20 \\
\hline 33 & $\begin{array}{ll}\text { Asia } & \text { Paper } \\
\text { Mill } & \end{array}$ & Media & 40 \\
\hline 34 & $\begin{array}{l}\text { Hossain } \\
\text { Pulp and } \\
\text { Paper Mill }\end{array}$ & Cigarette & 10 \\
\hline 35 & $\begin{array}{l}\text { Hossain } \\
\text { Pulp and } \\
\text { Paper Mill }\end{array}$ & Duplex & 40 \\
\hline 36 & $\begin{array}{l}\text { Bangla } \\
\text { tissue Mill }\end{array}$ & Tissue & 5 \\
\hline 37 & $\begin{array}{l}\text { Amber } \\
\text { Paper Mill }\end{array}$ & Writing & 20 \\
\hline 38 & $\begin{array}{l}\text { Amber } \\
\text { Paper Mill }\end{array}$ & Writing & 20 \\
\hline 39 & $\begin{array}{ll}\text { Lina } & \text { Paper } \\
\text { Mills } & \\
\end{array}$ & Writing & 70 \\
\hline 40 & $\begin{array}{l}\text { Baizid } \\
\text { Newsprint }\end{array}$ & Newsprint//Liner & 40 \\
\hline 41 & $\begin{array}{l}\text { Adunik } \\
\text { Paper Mill }\end{array}$ & Writing/Liner & 30 \\
\hline 42 & $\begin{array}{l}\text { Padma } \\
\text { Paper MIll }\end{array}$ & Liner/ Newsprint & 40 \\
\hline 43 & $\begin{array}{l}\text { Universal } \\
\text { Paper Mills }\end{array}$ & Media/Liner & 15 \\
\hline 44 & $\begin{array}{l}\text { Union paper } \\
\text { Mills }\end{array}$ & & 15 \\
\hline 45 & $\begin{array}{l}\text { Bangladesh } \\
\text { Paper Mills }\end{array}$ & & 40 \\
\hline 46 & $\begin{array}{l}\text { Mokka } \\
\text { Paper Mills }\end{array}$ & & 20 \\
\hline 47 & $\begin{array}{ll}\text { Gazi } & \text { Paper } \\
\text { Mills } & \\
\end{array}$ & & 20 \\
\hline 48 & $\begin{array}{ll}\text { City } & \text { Paper } \\
\text { Mills } & \\
\end{array}$ & & 20 \\
\hline 49 & $\begin{array}{l}\text { Arefin paper } \\
\text { Mills }\end{array}$ & & 25 \\
\hline 50 & $\begin{array}{ll}\text { Nice } & \text { Paper } \\
\text { Mills } & \\
\end{array}$ & & 30 \\
\hline 51 & $\begin{array}{l}\text { Uzzal Paper } \\
\text { Mills }\end{array}$ & & 10 \\
\hline 52 & $\begin{array}{l}\text { Creative } \\
\text { Paper Mill }\end{array}$ & Writing-printing & 100 \\
\hline 53 & $\begin{array}{l}\text { Capital } \\
\text { Paper Mills }\end{array}$ & Writing & 100 \\
\hline Total & & & 1537 \\
\hline
\end{tabular}


B. Chittagong region:

\begin{tabular}{|c|c|c|c|}
\hline Sl. No. & $\begin{array}{l}\text { Name of } \\
\text { the Paper } \\
\text { Mills }\end{array}$ & $\begin{array}{l}\text { Paper } \\
\text { Grades }\end{array}$ & $\begin{array}{l}\text { Product } \\
\text { ion, } \\
\text { TPD }\end{array}$ \\
\hline 1 & $\begin{array}{l}\text { Hakkani } \\
\text { Pulp and } \\
\text { Paper Mill }\end{array}$ & $\begin{array}{l}\text { Writing - } \\
\text { printing/Ne } \\
\text { wsprint }\end{array}$ & 20 \\
\hline 2 & $\begin{array}{l}\text { Hakkani } \\
\text { Board } \\
\text { Mills }\end{array}$ & $\begin{array}{l}\text { Media/Lin } \\
\text { er }\end{array}$ & 18 \\
\hline 3 & $\begin{array}{l}\text { Hakkani } \\
\text { Board } \\
\text { Mills } \\
\end{array}$ & $\begin{array}{l}\text { Media/Lin } \\
\text { er }\end{array}$ & 15 \\
\hline 4 & $\begin{array}{l}\text { Mostafa } \\
\text { Paper } \\
\text { Mills } \\
\end{array}$ & $\begin{array}{l}\text { Media/Lin } \\
\text { er }\end{array}$ & 18 \\
\hline 5 & $\begin{array}{l}\text { Anawara } \\
\text { Paper } \\
\text { Mills } \\
\end{array}$ & Newsprint & 5 \\
\hline 6 & $\begin{array}{l}\text { Anawara } \\
\text { paper } \\
\text { Mills } \\
\end{array}$ & $\begin{array}{l}\text { Media/Lin } \\
\text { er }\end{array}$ & 10 \\
\hline 7 & $\begin{array}{l}\text { MEB } \\
\text { Paper } \\
\text { Mills } \\
\end{array}$ & $\begin{array}{l}\text { Media/kraf } \\
\text { t Liner }\end{array}$ & 20 \\
\hline 8 & $\begin{array}{l}\text { T.K. Paper } \\
\text { Mill }\end{array}$ & $\begin{array}{l}\text { Writing- } \\
\text { printing/off } \\
\text { set }\end{array}$ & 75 \\
\hline 9 & $\begin{array}{l}\text { T.K. board } \\
\text { mill }\end{array}$ & $\begin{array}{l}\text { Duplex } \\
\text { board }\end{array}$ & 40 \\
\hline 10 & G.C. Box & $\begin{array}{l}\text { Media/Lin } \\
\text { er }\end{array}$ & 10 \\
\hline 11 & $\begin{array}{l}\text { Mack } \\
\text { paper Mill }\end{array}$ & $\begin{array}{l}\text { Media/kraf } \\
\text { t Liner }\end{array}$ & 20 \\
\hline 12 & $\begin{array}{l}\text { Chittagong } \\
\text { Asia Paper } \\
\text { Mill }\end{array}$ & $\begin{array}{l}\text { Media/Kra } \\
\mathrm{ft} \\
\text { Liner/New } \\
\text { sprint }\end{array}$ & 50 \\
\hline 13 & $\begin{array}{l}\text { Motaleb } \\
\text { Paper Mill }\end{array}$ & $\begin{array}{l}\text { Media/Lin } \\
\text { er }\end{array}$ & 10 \\
\hline 14 & $\begin{array}{l}\text { S.A. Pulp } \\
\text { and Paper } \\
\text { Mill }\end{array}$ & $\begin{array}{l}\text { Media/Ne } \\
\text { wsprint/Wr } \\
\text { iting- } \\
\text { printing }\end{array}$ & 40 \\
\hline 15 & $\begin{array}{l}\text { Export } \\
\text { Pack Ltd. }\end{array}$ & $\begin{array}{l}\text { Media/Kra } \\
\mathrm{ft} \\
\text { Liner/New } \\
\text { sprint }\end{array}$ & 20 \\
\hline 16 & $\begin{array}{l}\text { Ma-zainab } \\
\text { paper Mill }\end{array}$ & Media & 20 \\
\hline 17 & $\begin{array}{l}\text { Baizid } \\
\text { Paper Mill }\end{array}$ & $\begin{array}{l}\text { Media/Kra } \\
\mathrm{ft} \text { liner }\end{array}$ & 35 \\
\hline 18 & $\begin{array}{l}\text { T.K. Paper } \\
\text { Mill }\end{array}$ & $\begin{array}{l}\text { Writing- } \\
\text { printing }\end{array}$ & 60 \\
\hline 19 & $\begin{array}{l}\text { Karnaphuli } \\
\text { Paper Mill } \\
\end{array}$ & $\begin{array}{l}\text { Writing- } \\
\text { printing }\end{array}$ & 25 \\
\hline 20 & $\begin{array}{l}\text { Karnaphuli } \\
\text { Paper Mill }\end{array}$ & $\begin{array}{l}\text { Writing- } \\
\text { printing }\end{array}$ & 25 \\
\hline 21 & Karnaphuli & Brown & 22 \\
\hline
\end{tabular}

\begin{tabular}{|l|l|l|c|}
\hline & Paper Mill & Sulphate & \\
\hline Total & & & 558 \\
\hline $\begin{array}{l}\text { Under } \\
\text { processing }\end{array}$ & Soudia \\
\hline 1 & Paper Mill & $\begin{array}{l}\text { Writing- } \\
\text { printing/Ne } \\
\text { wsprint }\end{array}$ & 80 \\
\hline 2 & $\begin{array}{l}\text { T.K. Paper } \\
\text { Mill }\end{array}$ & $\begin{array}{l}\text { Writing- } \\
\text { printing/Ci } \\
\text { g/Tissue }\end{array}$ & 20 \\
\hline 3 & $\begin{array}{l}\text { T.K. Paper } \\
\text { Mill }\end{array}$ & $\begin{array}{l}\text { Writing- } \\
\text { printing/Ci } \\
\text { g/Tissu }\end{array}$ & 20 \\
\hline 4 & $\begin{array}{l}\text { T.K. Paper } \\
\text { Mill }\end{array}$ & $\begin{array}{l}\text { Writing- } \\
\text { printing/Ci } \\
\text { g/Tissu }\end{array}$ & 20 \\
\hline 5 & $\begin{array}{l}\text { T.K. Paper } \\
\text { Mill }\end{array}$ & Newsprint & 250 \\
\hline 6 & $\begin{array}{l}\text { Mir Paper } \\
\text { Mill }\end{array}$ & $\begin{array}{l}\text { Writing- } \\
\text { printing }\end{array}$ & 60 \\
\hline Total & Note: The statistics are around 5 yrs old. & 450 \\
\hline
\end{tabular}

The capacities of single paper machine mentioned above vary from 10 tpd to 250 tpd. They produce different grades of paper e.g., writing, printing, packaging, liner, media, simplex, duplex, board, newsprint, tissue, cigarette, etc. Single paper mill is able to produce more than one grade. Total capacity is around $2500 \mathrm{MT} /$ day, i.e., $2500 \times 300=7,00,000$ MT/yr (around). Now producing around $2000 \times 300$ $=500000-600000 \mathrm{MT} / \mathrm{yr}$.

Although there are almost 80 paper mills, only KPML is the integrated pulp and paper industry in Bangladesh. All other mills don't produce pulps but fully dependent on foreign pulps and recycle fibre. The capacity of KPML was 100 tpd, but now producing around 20000$25000 \mathrm{MT} / \mathrm{yr}$. The share of KPM is less than 5\% of total paper production in the country, but KPML produces both bleached and unbleached virgin pulps. Among the varieties of paper production - writing, printing, packaging (kraft/brown sulphate) and specialty papers are important. Almost cent percent of quality paper produced by KPM is consumed by govt. enterprises. KPM is not able to fulfill govt. demand. First, the problems faced by KPML and scope of development is iscussed. Later on, scope of development in this sector in Bangladesh is presented.

\section{KPML: CHALLENGES \& SCOPE OF DEVELOPMENT}

There are lot of shortcomings, and challenges faced by KPM. The major problems are insufficient main fibrous raw material (bamboo, wood), problems related to 
insufficient desired recycle fibre, foreign pulps, chemicals (filler materials, sizing chemicals, $\mathrm{Na}_{2} \mathrm{So}_{4}$, lime, salt, etc.), use of old technology/technique, old machineries, too long chain management, problem related to importing system, PSI- pre shipment inspection - system, union activities, multi dimensional 'TADBIR', illegal activities, corruption, etc.

3.1 Raw Materials: Wood and Non-wood (NW); Virgin Fibre (VF) and Recycle Fibre (RF)

Wood and Nonwood: KPM produces virgin fibre. Shortage of fibrous raw materials (wood, bamboo) is the regular problem of KPM. Worldwide around $90 \%$ of the total fibrous raw materials (FRM) comes from wood and remaining $10 \%$ are non-wood raw materials (RM). But around $80 \%$ of this non-wood RMs are used in Asia. This area is suffering from pulp-wood production because of many unavoidable reasons (high population, less land, climate, soil property, knowledge, etc.). NW plays a vital role in pulp and paper sector in Asia as well as in Bangladesh. Soft wood (SW) spruce, pine; and hard wood (HW) - eucalyptus, birch, beech, acacia, etc. are the main fibre source in major pulp and paper producing countries in the world. The main raw materials in $\mathrm{BD}$ are bamboo, mixed tropical HW, gawa, bagasse, etc. Many of the major pulp producing companies in the world have their own forest and they cultivate specific species, e.g., spruce or pine, or birch or beech or eucalyptus, etc. They get the advantage of processing of uniform chips in terms of physical properties and chemical composition and able to produce uniform pulp quality with minimum chemical cost. The soil of Asia including Bangladesh is not favorable for growing SW but good for HW. Mills don't have their own forest. The culture has not yet developed to produce a single species at a specific forest. KPM uses mixed FRM- MTHW, bamboo etc. \& is not able to produce uniform chips \& pulp quality which is prerequisite for paper $\mathrm{m} / \mathrm{c}$ runnability, paper quality as well as productivity.

Recycle Fibre (RF): World wide around $45 \%$ of the total fibrous raw materials used in paper sector is recycle fibre and the remaining $55 \%$ is virgin fibre. It is, also, suggested that the share of the RF will increase in future indicating the huge importance of RF in this sector. As already mentioned KPM produces the virgin fibre and always intends to produce more and more VF. Although KPM has started to use RF, but, unfortunately, the share of RF is only around $10 \%$ or less of the total furnish. The paper mills in private sector don't produce virgin fibre, but they use RF in combination with a little imported VF.

KPM should use more RF in place of VF. It requires to establish a deinking plant and at the same time to meet

the property requirement it will have to reinforce a fraction of imported long fibre (soft wood bleached kraft pulp). KPM is facing problems with importing of desirable foreign pulp which has obstructed smooth running of the mill.

\subsection{Bamboo Yard}

KPM has the chipping facilities both inside the mill (Chandraghona chipper) and outside the mill (Kaptai chipper). The mill is suffering from insufficient supply of FRM due to shortage of fibrous raw materials. Sometimes total supply is not up to the mark, sometimes the bamboo to wood ratio is not maintained, often the wood quality is poor (bark), sometimes the supply is irregular. To provide sufficient stock at Chandraghona as well as at Kaptai lake with a bamboo to wood ratio as per design (70:30), and to follow firstin first-out technique may solve the problem.

\subsection{Chipper}

In Kraft cook chip thickness is critical. A new chipper with modern chipping technique with good screening facilities can provide uniform chip ( 1 in / 0.5 in / 0.25 in), which is prerequisite for homogeneous pulp properties.

\subsection{Digester}

KPM uses batch digester and produces both bleached and unbleached pulps. Capacity of a single digester is $10 \mathrm{MT} / \mathrm{batch}$ and able to produce around $60 \mathrm{MT} / \mathrm{day}$. This technology is old but still working. The chronological development and widely used cooking technologies are Batch Cooking, Super Batch Cooking, Continuous Cooking (MC), Modified Continuous Cooking (MCC), Extended Modified Continuous Cooking (EMCC), Isothermal Continuous Cooking (ITC), etc. One single fibre line is able to produce 500 MT pulp/day. All these technologies are highly automated and being economic when produced large amount of pulp, e.g., 400-500 MT/day.

\subsection{Bleach Plant}

KPM traditionally uses hypochlorite bleaching (C-E-H$\mathrm{E}-\mathrm{H})$. This is a very old process/technique and it is corrosive. The yield is low. A chronological development of bleach technology of today is as follows:

Hypo bleaching

Chlorine bleaching

Elemental chlorine free bleaching (ECF)

Total chlorine free bleaching (TCF)

$$
\begin{aligned}
& \mathrm{CaOCl}_{3} \\
& \mathrm{Cl}_{2} \\
& \mathrm{ClO}_{2} \\
& \mathrm{H}_{2} \mathrm{O}_{2}, \mathrm{O}_{2}, \mathrm{O}_{3}, \text { PAA, } \\
& \text { etc }
\end{aligned}
$$


The next development target is minimum effluent pulp mill and finally effluent free pulp mill, and closed cycle paper mill. KPM bleach sequence is C-E-H-E-H, where $\mathrm{C}=$ chlorination with $\mathrm{Cl}_{2}, \mathrm{E}=$ extraction with $\mathrm{NaOH}$, and $\mathrm{H}=$ bleaching with calcium hypochlorite. Major bleaching sequences used in modern mills are presented below.

\begin{tabular}{|c|c|c|}
\hline i. & D -E-D-E-D & $\begin{array}{l}\text { where, } \mathrm{D}=\mathrm{ClO}_{2}, \mathrm{E}= \\
\text { extraction with } \mathrm{NaOH}\end{array}$ \\
\hline ii. & D -E-D-D & $\mathrm{E}=$ extraction with $\mathrm{NaOH}$ \\
\hline iii. & D -E-D & \\
\hline iv. & $\mathrm{D}_{\mathrm{O}}-\mathrm{E}_{\mathrm{O} / \mathrm{P}}-\mathrm{D}-\mathrm{E}-\mathrm{D}$ & $\begin{array}{l}\mathrm{D}_{\mathrm{O}}=\mathrm{ClO}_{2} \text { bleaching } \\
\text { presence of oxygen }\end{array}$ \\
\hline v. & $\mathrm{D}_{\mathrm{O}}-\mathrm{E}_{\mathrm{O} / \mathrm{P}}-\mathrm{D}-\mathrm{D}$ & $\begin{array}{l}\mathrm{E}_{\mathrm{O} / \mathrm{P}}=\text { Extraction with } \mathrm{NaOH} \\
\text { in presence of } \\
\text { oxygen/peroxide }\end{array}$ \\
\hline
\end{tabular}

vi. $\mathrm{D}_{\mathrm{O}}-\mathrm{E}_{\mathrm{O} / \mathrm{P}}-\mathrm{D}$

vii etc

Bleach sequence, chemicals and number of steps depend on target brightness, end use purpose of the pulp and environmental factors, etc. KPM has already planned to modernize its bleach plant during current BMR.

\subsection{Oxygen Delignification}

The aim of the oxygen delignification is to reduce the Kappa number with improved selectivity prior to the bleach plant. Oxygen acts as a delignification agent in the front section of the bleaching sequences, e.g., ECF and TCF. The wash filtrate from the oxygen delignification can be re-circulated to the digester, which improves selectivity. The oxygen stage can easily delignify 30-50\% of the residual lignin without excessive fibre degradation. The development of oxygen delignification and brown stock bleaching has been supported by environmental, economic and energy-related features. The oxygen stage can increase the delignification rate by $40-70 \%$ and improve screened pulp yield by $2-3 \%$ as well as better the pulp quality in comparison with that of the extended delignification. Less lignin and lignin-based residues to the bleach plant mean lower bleach-chemical consumption. A lower Kappa number also facilitates the environmentally benign ECF and TCF bleaching sequences $(1,4)$.

Reactions between oxygen and pulp components are complex. Oxygen reacts not only with lignin but also with carbohydrates and some contaminating substances in the pulp, e.g., bark particles, shives and dissolved organic compounds, which subsequently decrease the pulp strength. The negative effects of alkaline oxygen treatment on fibre quality is overcome by application of chelating agents (magnesium compounds) in the process (2). On the other hand, oxygen delignification is sensitive to the process conditions - pressure, temperature, residence time, chelant, etc. Oxygen delignification was invented before 45 years and as an industrial process 30 years old. KPM has already installed an O-delignification plant during current BMR.

\subsection{Recovery Plant}

There is a saying that 'Chemical Recovery Plant' is the heart of a Kraft/Sulphate pulp mill. The name of the 'Sulphate Process' is related to the sodium sulphate $\left(\mathrm{Na}_{2} \mathrm{SO}_{4}\right)$ make-up at soda recovery (SR) boiler. The difference between soda and sulphate process is that there is no sulphur with cooking liquor in soda process but sulphate-process cooking liquor contained sulphur (as $\mathrm{Na}_{2} \mathrm{~S}$ ). The speciality of sulphate/Kraft pulp is that it produces the strongest pulp. Both the strength and yield of Kraft pulp is higher than that conventional soda pulp. Higher yield is related to paper mill economy and higher fibre strength is related to the paper machine runnability as well as productivity. Sulphidity of cooking liquor is another important factor. To get the real benefits of sulphate cooking, it is a prerequisite to maintain a minimum level of sulphidity, e.g., around 20-25\% in some cases even more. So, this is very important to keep the recovery plant in operation maintaining a reasonable efficiency level.

\subsection{Stock Preparation}

Traditionally KPM was using acidic alum-rosin sizing chemicals, but has now introduced neutral sizing chemicals. Previously the furnish was $70 \%$ own pulp, $20 \%$ SPPM pulp and around $10 \%$ foreign pulp. After the shut-down of SPPM, now the furnish is own pulp, a portion $(\sim 10 \%)$ recycle fibre and a remarkable portion of filler materials. Here is a great scope to improve the share of recycle fibre in stock. The other areas are reuse of back water/ white water at beater side, also, can be interlinked with bleach plant, use of more OCC and RF (PM-3) and furnish can be balanced in combination with a little fraction of imported unbleached Kraft long fibre, etc.

\subsection{Paper Machine}

Productivity depends on many factors including paper machine runnability. Among the different options, 
screening facilities are very important to improve the machine performance. The smooth operation of at least one screening unit, e.g., pressure screen can improve the paper machine performance (will reduce the break frequency). At the same time usages ratio will be reduced as well as will improve the overall productivity.

\subsection{Environmental Management}

Although there are very few industries under government ownership but industries are growing in private sector indicating more load on environment. Pressure from 'Environmental Management Department' will increase in future. KPM has already planned to install a complete effluent treatment plant (ETP) during next BMR program. It will improve the current pollution situation as well as will facilitate the internal recirculation options.

\section{SCOPE OF IMPROVING KPM'S PERFORMANCE}

Some suggestions are listed below for improving KPM's performance:

i. Look for new fibre source, new plantation area, new and unique fast growing pulpwood species, etc.

ii. Improvement of the share of recycle fibre in place of virgin fibre and RF handling facilities, etc.

iii. To keep intact the current improvement of the filler content with the addition of a fraction of SBKP,

iv. Efficient operation of chemical recovery plant aiming at producing chemicals for kraft pulp,

v. Reuse the white/back water will improve the usages ratio and overall productivity of the mill,

vi. Addition of one more pulper only for PM-3 can increase the total pulp production and productivity,

vii. Operation of screening units can improve the PM performance, paper quality and productivity.

\section{SCOPE OF DEVELOPMENT OF PAPER SECTOT IN BANGLADESH}

All paper mills in Bangladesh are producing around 600000 MT paper and board/yr. The demand of paper and board is around $600000-700000 \mathrm{MT} / \mathrm{yr}$. If we grow up to Asia level, our consumption will increase to 10 times of current consumption. The per capita paper consumption as well as total paper consumption are increasing all over the developing countries and also in Bangladesh. It will increase further in future (must ?). So, there will be huge demand of paper and board in near future. Only KPM is producing virgin fibre but insufficient. No other mill in BD produces pulp, but only paper and board. These mills used to import pulps from foreign countries. There are huge demand of virgin fibres. So, it is required to establish a number of pulp mills to fulfill the demand of virgin fibre. The raw materials for pulp mill is wood and bamboo or other fibrous raw materials. We don't have much wood/bamboo or any other fibous raw materials to fulfill the demand of pulp mill.

About $10 \%$ of the land area of Bangladesh encompassing Rangamati, Bandarban, Khagrachori hill districts, etc. is partially used or uneconomically used or remained completely unused. This land area can be used for producing fast growing pulp-wood. KPM and other newly built pulp mills (probable) can thus become self sufficient with main fibrous raw materials within next 10 years. The balance can be fulfilled with recycle fibre and imported long fibre. Through the process, also, a huge number of employment opportunities will be created.

\section{REFERENCES}

1. Danielsson, L., (1995), Oxygen delignificationOperations, Bleach Plant Operations Short Course, pp. 4.2.1-4.2.44.

2. Quader, M.M.A., (2003), Improvement of the Alkaline Delignification of Wood and Nonwood Raw Materials for Pulp Production, D.Sc. thesis, Laboratory of Pulping Technology, Faculty of Ch.E, Åbo Akademi University, Åbo, Finland.

3. Smook, G.A., (1992), Handbook for pulp and paper technology, Second edition, Angus Wilde Publications.

4. Tench, L. and Harper, S., (1987), Oxygen-bleaching practices and benefits: An overview, Tappi, vol. 70, no. 11: pp. 55-61.

5. Hamilton, F., and Lleopold, B., Pulp and Paper Manufacture, Vol 3 Secondary Fibers and Non-Wood Pulping. 